\title{
Rевенсн Автіск: Knowledge level of beneficiary and non-beneficiary red gram farmers
}

S. Prashanth, S.G. Aski and S.H. Gotyal

Article Chronicle:

Received :

23.06.2020;

Revised:

18.09.2020;

Accepted :

06.10 .2020

KeY WoRds :

Knowledge level, Beneficiary, Nonbeneficiary, Red gram

Author for correspondence :

S.G. Aski

Department of

Agricultural Extension

Education, College of

Agriculture (UAS),

Vijayapur (Karnataka)

India

Email: askisubhash@

gmail.com

See end of the article for authors' affiliations
SUMMARY : The research was conducted in Vijayapura district of Karnataka during the year 2019-20 with the sample size of 120 respondents. The findings revealed that, in case of beneficiary farmers about 40.00 per cent of red gram farmers were belonged to high level of knowledge. In case of nonbeneficiary farmers about 38.33 per cent of red gram farmers were belonged to medium level of knowledge. It is clear that, in case of beneficiary farmers about cent $(100.00 \%)$ per cent of the respondents had knowledge about improved red gram variety, recommended seed rate, recommended spacing, irrigation frequency, intercultivation, weeding, important pests, pest control, important diseases, harvesting and post-harvesting. In case of non-beneficiary farmers it is revealed that, cent $(100.00 \%)$ per cent of the respondents had knowledge about weeding and post-harvesting, 98.33 per cent of the red gram farmers had knowledge about inter cultivation, 90.00 per cent of the red gram farmers had knowledge about time of sowing, 86.67 per cent of the red gram farmers had knowledge about important diseases, 85.00 per cent of the red gram farmers had knowledge about disease control.

How to cite this article : Prashanth, S., Aski, S.G. and Gotyal, S.H. (2020). Knowledge level of beneficiary and non-beneficiary red gram farmers. Agric. Update, 15(4): 293-297; DOI : 10.15740/HAS/AU/15.4/293-297. Copyright@2020: Hind Agri-Horticultural Society. 